\title{
Role of Mycoplasma pneumoniae infection in acute exacerbations of chronic obstructive pulmonary disease
}

Correspondence

Mandira Varma-Basil

mandirav@rediffmail.com

Received 12 May 2008

Accepted 27 November 2008

\author{
Mandira Varma-Basil, ${ }^{1}$ Shailendra K. D. Dwivedi, ${ }^{1}$ Krishna Kumar, ${ }^{1}$ \\ Rakesh Pathak, ${ }^{1}$ Ritika Rastogi, ${ }^{1}$ S. S. Thukral, ${ }^{1}$ Malini Shariff, ${ }^{1}$ \\ V. K. Vijayan, ${ }^{2}$ Sunil K. Chhabra ${ }^{2}$ and Rama Chaudhary ${ }^{3}$ \\ ${ }^{1}$ Department of Microbiology, V. P. Chest Institute, University of Delhi, Delhi, India \\ ${ }^{2}$ Department of Respiratory Medicine, V. P. Chest Institute, University of Delhi, Delhi, India \\ ${ }^{3}$ Department of Microbiology, All India Institute of Medical Sciences, New Delhi, India
}

\section{INTRODUCTION}

Chronic obstructive pulmonary disease (COPD) is defined by the presence of irreversible or partially reversible airway obstruction in patients with chronic bronchitis or emphysema (Gross, 2001). The prolonged course of COPD is characterized by recurrent episodes of acute exacerbations, defined by a subjective increase from baseline of one or more symptoms including dyspnoea, cough, sputum production, sputum purulence and sputum tenacity (ATS, 1995). While several factors cause exacerbations of COPD (Sethi, 2000), the pathophysiology is infectious in about $80 \%$ of cases. There are several reports in which Mycoplasma pneumoniae has been identified as an aetio-

Abbreviations: AECOPD, acute exacerbations of chronic obstructive pulmonary disease; GPA, Gelatin Particle Agglutination. logical agent in $0.5-2.4 \%$ of acute exacerbations of chronic bronchitis and COPD (Gump et al., 1976; Buscho et al., 1978; Smith et al., 1980; Allegra et al., 1994; Lieberman et al., 2001, 2003). However, some other workers did not find any evidence of $M$. pneumoniae infection in acute exacerbations of COPD (AECOPD) (Goh et al., 1999; Diederen et al., 2007). Thus the role of M. pneumoniae in AECOPD remains unclear and controversial. It is important to delineate the extent of involvement of $M$. pneumoniae in this disease syndrome in order to be able to plan empirical therapeutic strategies. To the best of our knowledge, no studies have been undertaken on the role of M. pneumoniae in AECOPD in Indian patients. The present study represents such an attempt, in patients attending the Clinical Research Center at Vallabhbhai Patel Chest Institute, Delhi, India. 


\section{METHODS}

Patients. One hundred adult AECOPD patients attending the Clinical Research Center at Vallabhbhai Patel Chest Institute, Delhi, India, between January 2004 and June 2006 were selected for the study. The inclusion criteria for the study were: a history of COPD, increased cough, dyspnoea and production of purulent sputum (ATS, 1995). The exclusion criteria were: treatment with any antibiotic for $24 \mathrm{~h}$ or longer within $72 \mathrm{~h}$ of the baseline visit, evidence of bronchiectasis and/or pneumonia, and malignancy or severe immunosuppression (Mogulkoc et al., 1999). All the patients were asked to report back for follow-up 2-3 weeks after the baseline visit. However, only 57 patients reported for follow up. Convalescent sera samples were collected from all of these 57 patients. In addition, 35 healthy volunteers were included in the study as the control group. Informed consent was taken from each patient and healthy volunteer prior to inclusion in the study, following clearance from the Institutional Ethical Committee.

Specimens. Throat swabs were collected from patients, including the follow-up cases, kept in PPLO broth (Difco) and transported to the laboratory. Morning expectorated sputum samples were also collected from the patients in sterile containers. Acute and convalescent phase sera were separated from the blood samples collected from the patients and stored at $-20{ }^{\circ} \mathrm{C}$ for further analysis.

A Gram stain was performed to evaluate the quality of expectorated sputum. Only specimens with fewer than 10 squamous epithelial cells and 25 or more polymorphonuclear leukocytes per low-power field were processed further. All the samples were subcultured on supplemented PPLO agar (Difco) and PPLO broth, as previously described (Marmion, 1989). The samples were also subcultured on $5 \%$ sheep blood agar and MacConkey agar. Blood agar and MacConkey agar plates were incubated for $24 \mathrm{~h}$ at $37{ }^{\circ} \mathrm{C}$. PPLO agar plates were incubated for 2-3 weeks. Pure culture or predominant growth of a bacterial isolate on blood agar or MacConkey agar was considered significant and the bacterial isolate was identified as per standard procedures (Collee \& Miles, 1989).

Serological tests. Specific $\operatorname{IgM}, \operatorname{IgG}$ and $\operatorname{IgA}$ antibodies to $M$. pneumoniae were determined in 100 acute phase sera, 57 convalescent phase sera as well as in 35 sera collected from healthy controls, using commercial ELISAs as per the manufacturer's instructions (SERION ELISA classic). Values of $>30 \mathrm{IU} \mathrm{ml}^{-1}$ for IgG, $>17 \mathrm{IU} \mathrm{ml}^{-1}$ for IgM and $>14 \mathrm{IU} \mathrm{ml}^{-1}$ for IgA were considered positive according to the manufacturer's recommendations. Samples giving IgG titres of 20-30 IU ml ${ }^{-1}$, IgM titres of 13-17 IU ml ${ }^{-1}$ and IgA titres of 10$14 \mathrm{IU} \mathrm{ml}^{-1}$ were considered borderline positive as recommended by the manufacturer. All the samples were also screened for the presence of anti-M. pneumoniae antibodies by employing the Microtitre Gelatin Particle Agglutination (GPA) assay (Fujirebio).

PCR. PPLO broth $(200 \mu \mathrm{l})$, inoculated with the throat swabs/sputum samples obtained from patients, was centrifuged for $30 \mathrm{~min}$ at $12000 \mathrm{~g}$. The pellet was resuspended in PBS $(500 \mu \mathrm{l})$ and washed twice. The final pellet was resuspended in $20 \mu \mathrm{l}$ distilled water, boiled for $15 \mathrm{~min}$ and centrifuged for $30 \mathrm{~s}$ at $10000 \mathrm{~g}$. The supernatant was used for PCR. An assay based on the P1 adhesin gene, using primers MpnA (5'-CCG CGA AGA GCA ATG AAA AAC TCC-3') and MpnB (5'-TCG AGG CGG ATC ATT TGG GGA GGT-3'), was used to obtain a 375 bp amplicon (Ramirez et al., 1996).

Samples were amplified for 35 cycles. Each cycle consisted of denaturation at $94{ }^{\circ} \mathrm{C}$ for $30 \mathrm{~s}$, annealing at $65^{\circ} \mathrm{C}$ for $30 \mathrm{~s}$, extension at $72{ }^{\circ} \mathrm{C}$ for $30 \mathrm{~s}$ and a final extension at $72{ }^{\circ} \mathrm{C}$ for $10 \mathrm{~min}$. The amplification products were examined on agarose gels. A $100 \mathrm{bp}$ molecular mass standard (Fermentas Life Sciences) was included in each gel. Strain FH (ATCC 15531) was used as positive control and sterile distilled water as negative control for the PCR.

Antigen assay. Antigen assay was carried out, using the SERION ELISA antigen kit for M. pneumoniae (Serion Virion), on 75 throat swabs taken from AECOPD patients at random, which also included all patients with serological evidence of $M$. pneumoniae infection. The assay was also carried out on 35 throat swabs from healthy volunteers. The throat swabs were emulsified and stored in PPLO broth. The specimens were diluted $1: 1$ with the specimen buffer provided in the ELISA kit and incubated at $37^{\circ} \mathrm{C}$ for $1 \mathrm{~h}$. The mixture was then centrifuged for $15 \mathrm{~min}$ and $100 \mu \mathrm{l}$ of the supernatant was used for ELISA. The microtitre plate was kept at $37^{\circ} \mathrm{C}$ for $1 \mathrm{~h}$ after addition of the supernatant. After washing, the conjugate consisting of anti- $M$. pneumoniae antibodies was added to the sample wells. The plate was incubated at $37{ }^{\circ} \mathrm{C}$ again for $30 \mathrm{~min} .3,3^{\prime}, 5,5^{\prime}$-Tetramethylbenzidine substrate solution was added to the plate and the plate was reincubated at room temperature for $20 \mathrm{~min}$. The reaction was stopped by adding the stopping solution and the $A_{450}$ was read.

Statistical analysis. Statistical comparisons were performed using the chi-square test or Fischer's exact test. The level of significance was defined as $P \leqslant 0.05$.

\section{RESULTS AND DISCUSSION}

Despite some studies associating M. pneumoniae with acute exacerbation of bronchial asthma and COPD, its role has not been unequivocally proven (Gump et al., 1976; Buscho et al., 1978; Smith et al., 1980; Allegra et al., 1994; Goh et al., 1999; Lieberman et al., 2001; Diederen et al., 2007). The present study was an attempt to delineate the role of $M$. pneumoniae in AECOPD in patients in India.

One hundred sputum samples and 100 throat swabs were taken from the same number of patients with AECOPD. Ninety-eight per cent of the patients were adult males. Fifty-six per cent of the patients were from the age group 60-79 years. Most of the patients presented with cough $(91 \%)$ and expectoration $(90 \%)$. None of the patients had any other underlying disorder. However, 10 patients had been treated for tuberculosis in the past.

Bacterial aetiology could be established in 16 of the 100 samples studied. None of the sputum samples were culture-positive for M. pneumoniae. Pseudomonas spp. were recovered from eight cases, Streptococcus pneumoniae from four, Klebsiella spp. from two, while Acinetobacter sp. and Moraxella catarrhalis were isolated from one case each. In three of these cases, one each with evidence of Klebsiella spp., S. pneumoniae and Pseudomonas spp. infection, the M. pneumoniae IgG antibody titre was positive. One patient from whom Pseudomonas sp. was isolated had a borderline IgA level $\left(12 \mathrm{IU} \mathrm{ml}^{-1}\right)$ in addition to an IgG titre of $150 \mathrm{IU} \mathrm{ml}^{-1}$, indicating the possibility of a mixed infection. Co-infection of M. pneumoniae with bacterial pathogens or viruses has also been reported in earlier studies (Lieberman et al., 2002).

ELISA assays for M. pneumoniae specific IgG, IgM and IgA antibodies were performed on all the serum samples. The IgG antibody titres were positive for $40 / 100$ acute phase 
serum samples (Table 1). The IgG titres in patients (mean $23.65 \pm 2.684)$ were significantly higher than in normal healthy control subjects (mean 13.99 $\pm 1.996 ; P<0.05$ ) (Fig. 1a). Convalescent phase sera were collected from 57/ 100 patients studied, of which 35 samples were obtained from patients with raised IgG titres during the first visit. There was no change in the $\operatorname{IgG}$ titres in 52 patients; however, 5 patients with a raised baseline IgG titre showed a fourfold rise (Table 2). IgM antibody titres for all of these 5 patients were, however, negative $\left(<10 \mathrm{IU} \mathrm{ml}^{-1}\right)$.

Five additional serum samples (Table 1) were positive in the IgM ELISA assay (mean 6.620 \pm 0.5568 ). Two of these five patients were also positive for M. pneumoniae specific antigen, but were culture- and PCR-negative. One of the control samples had positive IgM titres (mean $6.057 \pm 0.3888$; $P>0.05$ ) (Fig. $1 b$ ). The number of IgMpositive samples in our study was low since our study population consisted of adult patients $\geqslant 40$ years of age. It has been observed that older patients having experienced multiple reinfections usually have only low or undetectable IgM concentrations (Barker et al., 1990).

Raised IgA antibodies (Table 1) were seen in significantly higher numbers of patients (mean $9.170 \pm 1.008$ ) than controls (mean $4.057 \pm 0.2167 ; P<0.05$ ) (Fig. 1c). Four patients with high IgA titres also had positive IgG titres, indicative of a primary M. pneumoniae infection.

Though none of the control subjects was positive for the GPA assay, 18 serum samples collected from AECOPD patients were positive for anti-M. pneumoniae antibodies by this assay. Three of these samples had a titre of $\geqslant 1: 320$ (Table 2). In addition, all three had raised IgG titres. Moreover, in one of these three patients the convalescent serum showed a fourfold rise in the titres of IgG antibodies, indicating active $M$. pneumoniae infection. Although the use of paired serum samples collected at an interval of at least 2 weeks is ideal for the demonstration of a rising titre, which in turn indicates active infection, a few workers have also used single serum samples and considered a GPA titre of $\geqslant 1: 320$ (Hirai et al., 1991) significant.
PCR for the $375 \mathrm{bp}$ fragment of the P1 adhesin gene was negative in all the 100 clinical samples studied. The possibility of PCR inhibitors in the sample interfering with the PCR assay has been indicated (Waites \& Talkington, 2004). Since we had not included an internal 'inhibitors' control in our PCR assays, it would not be possible for us to assess whether PCR inhibitors had an impact on our results.

The M. pneumoniae specific antigen was detected in 3 of 75 throat swabs tested from AECOPD patients, while none of the samples from healthy control subjects were positive. Of the antigen-positive samples, one sample was also positive for IgG $\left(85 \mathrm{U} \mathrm{ml}^{-1}\right)$. Another sample was positive for both $\operatorname{IgM}\left(25 \mathrm{U} \mathrm{ml}^{-1}\right)$ and $\operatorname{IgG}\left(32 \mathrm{U} \mathrm{ml}^{-1}\right)$ antibodies. The third sample was positive for IgM $\left(26 \mathrm{U} \mathrm{ml}^{-1}\right)$ and $\operatorname{IgG}$ $\left(42 \mathrm{U} \mathrm{ml}^{-1}\right)$ and borderline positive for IgA antibodies. However, the antigen-positive samples in our study were negative by PCR as well as culture. It is possible to detect non-specific cross-reactive antigens of other mycoplasmas in the respiratory tract (Waites \& Talkington, 2004). In addition, as mentioned earlier, the possibility of PCR inhibitors interfering with the PCR assay also has to be considered (Waites \& Talkington, 2004).

The criteria used to identify the possibility of $M$. pneumoniae infection in the study population are described in Table 2. On the basis of serology and antigen assay, $16 \%$ of our patients could be considered showing evidence of $M$. pneumoniae infection. This corroborates the findings of earlier studies which reported a higher seroprevalence of M. pneumoniae in AECOPD patients than in the healthy controls (Mogulkoc et al., 1999; Park et al., 2005). Another study, however, did not find any serological evidence of $M$. pneumoniae infection in severe exacerbations of COPD requiring ventilation (Soler et al., 1998). A more recent study found no indication for a role of atypical bacteria, including M. pneumoniae, in either stable COPD or in its exacerbations (Diederen et al., 2007). In our study, too, we did not get direct evidence by isolation and/or detection by PCR of M. pneumoniae. Although the seroprevalence of $M$. pneumoniae infection in our study population was

Table 1. Results of detection of $M$. pneumoniae antibodies by ELISA in the acute phase serum samples

\begin{tabular}{|c|c|c|c|c|c|c|c|c|c|c|}
\hline \multirow[t]{2}{*}{ Sample no. } & \multirow{2}{*}{$\begin{array}{l}\text { Serological } \\
\text { assay }\end{array}$} & \multicolumn{4}{|c|}{ Patient group $(n=100)$} & \multicolumn{4}{|c|}{ Control group $(n=35)$} & \multirow[t]{2}{*}{$P$-value } \\
\hline & & $\begin{array}{c}\text { No. } \\
\text { negative }\end{array}$ & $\begin{array}{c}\text { No. } \\
\text { positive }\end{array}$ & $\begin{array}{l}\text { No. border- } \\
\text { line positive }\end{array}$ & $\begin{array}{c}\text { Total } \\
\text { positive }\end{array}$ & $\begin{array}{c}\text { No. } \\
\text { negative }\end{array}$ & $\begin{array}{c}\text { No. } \\
\text { positive }\end{array}$ & $\begin{array}{l}\text { No. border- } \\
\text { line positive }\end{array}$ & $\begin{array}{c}\text { Total } \\
\text { positive }\end{array}$ & \\
\hline 1 & $\operatorname{IgG}$ & 60 & 31 & 9 & 40 & 31 & 3 & 1 & 4 & $<0.01$ \\
\hline 2 & IgM & 95 & 4 & 1 & 5 & 34 & 1 & 0 & 1 & $>0.05$ \\
\hline 3 & IgA & 75 & 13 & 12 & 25 & 35 & 0 & 0 & 0 & $<0.01$ \\
\hline 4 & $\operatorname{IgG}+\operatorname{Ig} A$ & - & 4 & $8^{*}$ & 12 & - & 0 & 0 & 0 & $<0.05$ \\
\hline 5 & $\operatorname{IgG}+\operatorname{IgM}$ & - & 0 & $1 \dagger$ & 1 & - & 1 & 0 & 1 & $>0.05$ \\
\hline 6 & $\operatorname{IgG}+\operatorname{Ig} M+\operatorname{Ig} A$ & - & 1 & 0 & 1 & - & 0 & 0 & 0 & - \\
\hline
\end{tabular}

${ }^{\star}$ Seven IgG-positive, IgA-borderline; one IgG-borderline, IgA-positive.

$\dagger$ IgM-positive, IgG-borderline. 

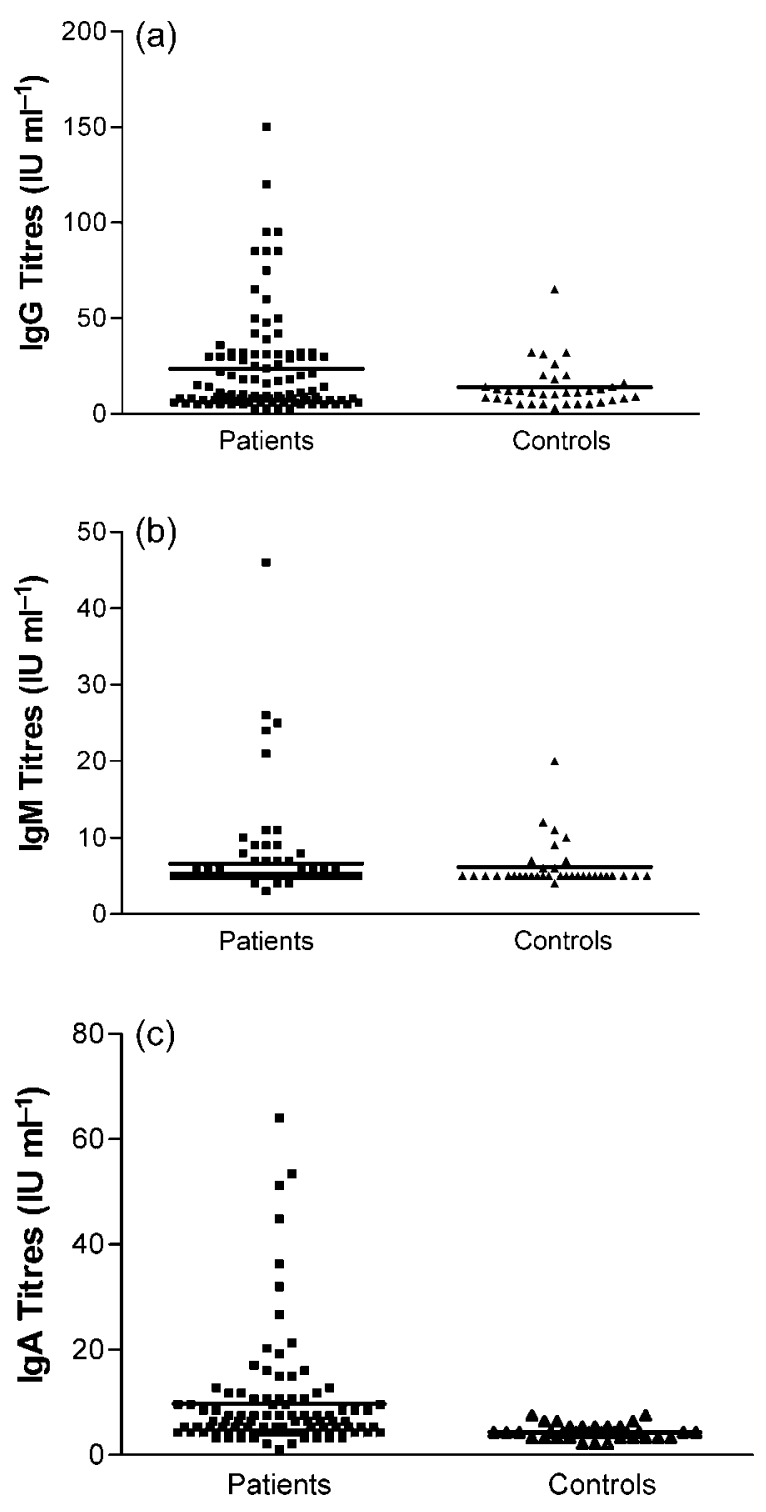

Fig. 1. M. pneumoniae specific antibody titres in patients ( $\boldsymbol{\square})$ and control $(\boldsymbol{\Lambda})$ subjects. The horizontal lines represent the mean of antibody titres in the two groups. (a) M. pneumoniae specific IgG titres. A value of $>30 \mathrm{IU} \mathrm{ml}^{-1}$ was taken as positive. The difference in the means of $\lg G$ titres of patients and control samples was statistically significant $(P<0.05)$. (b) M. pneumoniae specific IgM titres. A value of $>17 \mathrm{IU} \mathrm{ml}^{-1}$ was taken as a positive lgM titre. The difference in the means of $\operatorname{lgM}$ titres of patients and control samples was not found to be statistically significant $(P>0.05)$. (c) $M$. pneumoniae specific $\lg A$ titres in patients and control subjects. A value of $>14 \mathrm{IU} \mathrm{ml}^{-1}$ was taken as a positive $\lg A$ titre. The difference in the means of $\lg A$ titres of patients and control samples was statistically significant $(P<0.05)$.

significantly higher than in the control group, the role, if any, played by M. pneumoniae in AECOPD could not be substantiated by culture isolation or detection by PCR. There is thus a need to undertake more studies in well-
Table 2. Criteria used to identify the possibility of recent $M$. pneumoniae infection

\begin{tabular}{|c|c|}
\hline Criteria for diagnosis & $\begin{array}{c}\text { Number } \\
\text { of samples } \\
\text { considered positive } \\
\text { for M. pneumoniae } \\
\text { infection }\end{array}$ \\
\hline \multicolumn{2}{|l|}{ Definitive diagnosis } \\
\hline 1. Isolation of $M$. pneumoniae in culture & 0 \\
\hline $\begin{array}{l}\text { 2. Nucleic acid amplification assay of P1 } \\
\text { adhesin gene }\end{array}$ & 0 \\
\hline $\begin{array}{l}\text { 3. Detection of } M \text {. pneumoniae antigen in } \\
\text { respiratory secretions with raised IgM }\end{array}$ & 2 \\
\hline 4. Fourfold rise of $\operatorname{IgG}$ titres & 5 \\
\hline \multicolumn{2}{|l|}{ Probable diagnosis } \\
\hline $\begin{array}{l}\text { 1. Detection of } M \text {. pneumoniae antigen (with } \\
\text { or without raised } \operatorname{IgG} / \operatorname{IgA} \text { ) }\end{array}$ & 1 \\
\hline 2. Raised IgM titre in serum alone & 2 \\
\hline $\begin{array}{l}\text { 3. Raised IgM and IgG titre in serum (without } \\
\text { the presence of antigen) }\end{array}$ & 0 \\
\hline 4. Raised IgG and IgA titre & $4^{*}$ \\
\hline 5. IgG titres $\geqslant 100 \mathrm{U}$ (Uldum et al., 1992) & 2 \\
\hline $\begin{array}{l}\text { 6. Titres of antibodies in GPA assay } \geqslant 1: 320 \\
\text { (Hirai et al., 1991) }\end{array}$ & $3 \dagger$ \\
\hline
\end{tabular}

*Two samples also had rising titres of IgG antibodies.

$\dagger$ One sample also had rising titres of IgG antibody.

defined patient populations of AECOPD to establish the correlation between serological evidence of M. pneumoniae infection and isolation by culture and detection by PCR.

\section{ACKNOWLEDGEMENTS}

Financial support for this study was provided by the Indian Council of Medical Research. We thank Dr Mujeeb-ur-Rahman for providing help with the statistical analysis.

\section{REFERENCES}

Allegra, L., Blasi, F., Centanni, S., Cosentini, R., Denti, F., Raccanelli, R., Tarsia, P. \& Valenti, S. (1994). Acute exacerbations of asthma in adults: role of Chlamydia pneumoniae infection. Eur Respir J 7, 21652168.

American Thoracic Society (1995). Standards for the diagnosis and care of patients with chronic obstructive pulmonary disease. Am J Respir Crit Care Med 152, S77-S121.

Barker, C. E., Sillis, M. \& Wreghitt, T. G. (1990). Evaluation of Serodia Myco II particle agglutination test for detecting Mycoplasma pneumoniae antibody: comparison with $\mu$-capture ELISA and indirect immunofluorescence. J Clin Pathol 43, 163-165.

Buscho, R. O., Saxtan, D., Shultz, P. S., Finch, E. \& Mufson, M. A. (1978). Infections with viruses and Mycoplasma pneumoniae during exacerbations of chronic bronchitis. J Infect Dis 137, 377-383.

Collee, J. G. \& Miles, R. S. (1989). Tests for identification of bacteria. In Mackie and McCartney's Practical Medical Microbiology, 13th edn, 
pp. 141-160. Edited by J. G. Collee, J. P. Duguid, A. G. Fraser \& B. P. Marmion. Edinburgh: Churchill Livingstone.

Diederen, B. M., van der Valk, P. D., Kluytmans, J. A., Peeters, M. F. \& Hendrix, R. (2007). The role of atypical respiratory pathogens in exacerbations of chronic obstructive pulmonary disease. Eur Respir $J$ 30, 240-244.

Goh, S. K., Johan, A., Cheong, T. H. \& Wang, Y. T. (1999). A prospective study of infections with atypical pneumonia organisms in acute exacerbations of chronic bronchitis. Ann Acad Med Singapore 28, 476-480.

Gross, N. J. (2001). The GOLD standard for chronic obstructive pulmonary disease. Am J Respir Crit Care Med 163, 1047-1048.

Gump, D. W., Phillips, C. A., Forsyth, B. R., McIntosh, K., Lamborn, K. R. \& Stouch, W. H. (1976). Role of infection in chronic bronchitis. Am Rev Respir Dis 113, 465-474.

Hirai, Y., Shiode, J., Masayoshi, T. \& Kanemasa, Y. (1991). Application of an indirect immunofluorescence test for detection of Mycoplasma pneumoniae in respiratory exudates. J Clin Microbiol 29, 2007-2012.

Lieberman, D., Lieberman, D., Ben-Yaakov, M., Lazarovich, Z., Hoffman, S., Ohana, B., Friedman, M. G., Dvoskin, B., Leinonen, M. \& Boldur, I. (2001). Infectious etiologies in acute exacerbation of COPD. Diagn Microbiol Infect Dis 40, 95-102.

Lieberman, D., Lieberman, D., Ben-Yaakov, M., Shmarkov, O., Gelfer, Y., Varshavsky, R., Ohana, B., Lazarovich, Z. \& Boldur, I. (2002). Serological evidence of Mycoplasma pneumoniae infection in acute exacerbation of COPD. Diagn Microbiol Infect Dis 44, 1-6.

Lieberman, D., Lieberman, D., Printz, S., Ben-Yaakov, M., Lazarovich, Z., Ohana, B., Friedman, M. G., Dvoskin, B., Leinonen, M. \& Boldur, I. (2003). Atypical pathogen infection in adults with acute exacerbation of bronchial asthma. Am J Respir Crit Care Med 167, 406-410.

Marmion, B. P. (1989). Mycoplasma: Acholeplasma: Ureaplasma. In Mackie and McCartney's Practical Medical Microbiology, 13th edn, pp. 745-768. Edited by J. G. Collee, J. P. Duguid, A. G. Fraser \& B. P. Marmion. Edinburgh: Churchill Livingstone.

Mogulkoc, N., Karakurt, S., Isalska, B., Bayindir, U., Celikel, T., Korten, V. \& Colpan, N. (1999). Acute purulent exacerbation of chronic obstructive pulmonary disease and Chlamydia pneumoniae infection. Am J Respir Crit Care Med 160, 349-353.

Park, S. J., Lee, Y. C., Rhee, Y. K. \& Lee, H. B. (2005). Seroprevalence of Mycoplasma pneumoniae and Chlamydia pneumoniae in stable asthma and chronic obstructive pulmonary disease. J Korean Med Sci 20, 225-228.

Ramirez, J. A., Ahkee, S., Tolentino, A., Miller, R. D. \& Summersgill, J. T. (1996). Diagnosis of Legionella pneumophila, Mycoplasma pneumoniae or Chlamydia pneumoniae lower respiratory infection using the polymerase chain reaction on a single throat swab specimen. Diagn Microbiol Infect Dis 24, 7-14.

Sethi, S. (2000). Infectious etiology of acute exacerbations of chronic bronchitis. Chest 117, 380S-385S.

Smith, C. B., Golden, C. A., Kanner, R. E. \& Renzetti, A. D., Jr (1980). Association of viral and Mycoplasma pneumoniae infections with acute respiratory illness in patients with chronic obstructive pulmonary diseases. Am Rev Respir Dis 121, 225-232.

Soler, N., Torres, A., Ewig, S., Gonzalez, J., Celis, R., El-Ebiary, M., Hernandez, C. \& Rodriguez-Roisin, R. (1998). Bronchial microbial patterns in severe exacerbations of chronic obstructive pulmonary disease (COPD) requiring mechanical ventilation. Am J Respir Crit Care Med 157, 1498-1505.

Uldum, S. A., Jensen, J. S., Sondergard-Andersen, J. \& Lind, K. (1992). Enzyme immunoassay for detection of immunoglobulin $M$ (IgM) and IgG antibodies to Mycoplasma pneumoniae. J Clin Microbiol 30, 1198-1204.

Waites, K. B. \& Talkington, D. F. (2004). Mycoplasma pneumoniae and its role as a human pathogen. Clin Microbiol Rev 17, 697-728. 